\title{
Nitrogen metabolism in haloarchaea
}

\section{María José Bonete*1, Rosa María Martínez-Espinosa ${ }^{1}$, Carmen Pire ${ }^{1}$, Basilio Zafrilla ${ }^{1}$ and David J Richardson ${ }^{2}$}

\author{
Address: ${ }^{1}$ División de Bioquímica y Biología Molecular, Facultad de Ciencias, Universidad de Alicante, Ap. 99, E-03080, Alicante, Spain and \\ ${ }^{2}$ School of Biological Sciences, Faculty of Science, University of East Anglia, Norwich, NR4 7TJ, UK \\ Email: María José Bonete* -mjbonete@ua.es; Rosa María Martínez-Espinosa - rosa.martinez@ua.es; Carmen Pire - carmen.pire@ua.es; \\ Basilio Zafrilla - basilio.zafrilla@ua.es; David J Richardson - D.Richardson@uea.ac.uk \\ * Corresponding author
}

Published: I July 2008

Saline Systems 2008, 4:9 doi:10.1186/1746-1448-4-9

This article is available from: http://www.salinesystems.org/content/4/I/9

(C) 2008 Bonete et al; licensee BioMed Central Ltd.

This is an Open Access article distributed under the terms of the Creative Commons Attribution License (http://creativecommons.org/licenses/by/2.0), which permits unrestricted use, distribution, and reproduction in any medium, provided the original work is properly cited.
Received: 15 January 2008

Accepted: I July 2008

\begin{abstract}
The nitrogen cycle ( $\mathrm{N}$-cycle), principally supported by prokaryotes, involves different redox reactions mainly focused on assimilatory purposes or respiratory processes for energy conservation. As the $\mathrm{N}$-cycle has important environmental implications, this biogeochemical cycle has become a major research topic during the last few years. However, although $\mathrm{N}$-cycle metabolic pathways have been studied extensively in Bacteria or Eukarya, relatively little is known in the Archaea. Halophilic Archaea are the predominant microorganisms in hot and hypersaline environments such as salted lakes, hot springs or salted ponds. Consequently, the denitrifying haloarchaea that sustain the nitrogen cycle under these conditions have emerged as an important target for research aimed at understanding microbial life in these extreme environments.

The haloarchaeon Haloferax mediterranei was isolated 20 years ago from Santa Pola salted ponds (Alicante, Spain). It was described as a denitrifier and it is also able to grow using $\mathrm{NO}_{3}^{-}, \mathrm{NO}_{2}^{-}$or $\mathrm{NH}_{4}{ }^{+}$as inorganic nitrogen sources. This review summarizes the advances that have been made in understanding the $\mathrm{N}$-cycle in halophilic archaea using $H f x$ mediterranei as a haloarchaeal model. The results obtained show that this microorganism could be very attractive for bioremediation applications in those areas where high salt, nitrate and nitrite concentrations are found in ground waters and soils.
\end{abstract}

\section{Background}

Nitrogen $(\mathrm{N})$ is a major element in all organisms. It accounts for approximately $6 \%$ of their dry mass on average and thus in nature its assimilation is a key process of the $\mathrm{N}$-cycle carried out by higher plants [1], algae [2], yeast [3], and bacteria [4]. In the environment, $\mathrm{N}$ can be found in different redox states from +5 (as nitrate) to -3 (as ammonia), but in biological compounds it is almost exclusively present in the most reduced form as a component of the two pre-eminent biological macromolecules: proteins and nucleic acids [5]. The reactions of the global biogeochemical $\mathrm{N}$-cycle makes possible the interconvertions of nitrogen compounds and it includes both reductive and oxidative processes, in which prokaryotes play a predominant role (Fig. 1).

The assimilatory pathways of the $\mathrm{N}$-cycle $\left(\mathrm{N}_{2}\right.$ fixation and nitrate assimilation) generate ammonium that is then incorporated into the carbon skeletons to produce amino acids. However, whereas $\mathrm{N}_{2}$ fixation is carried out by free- 


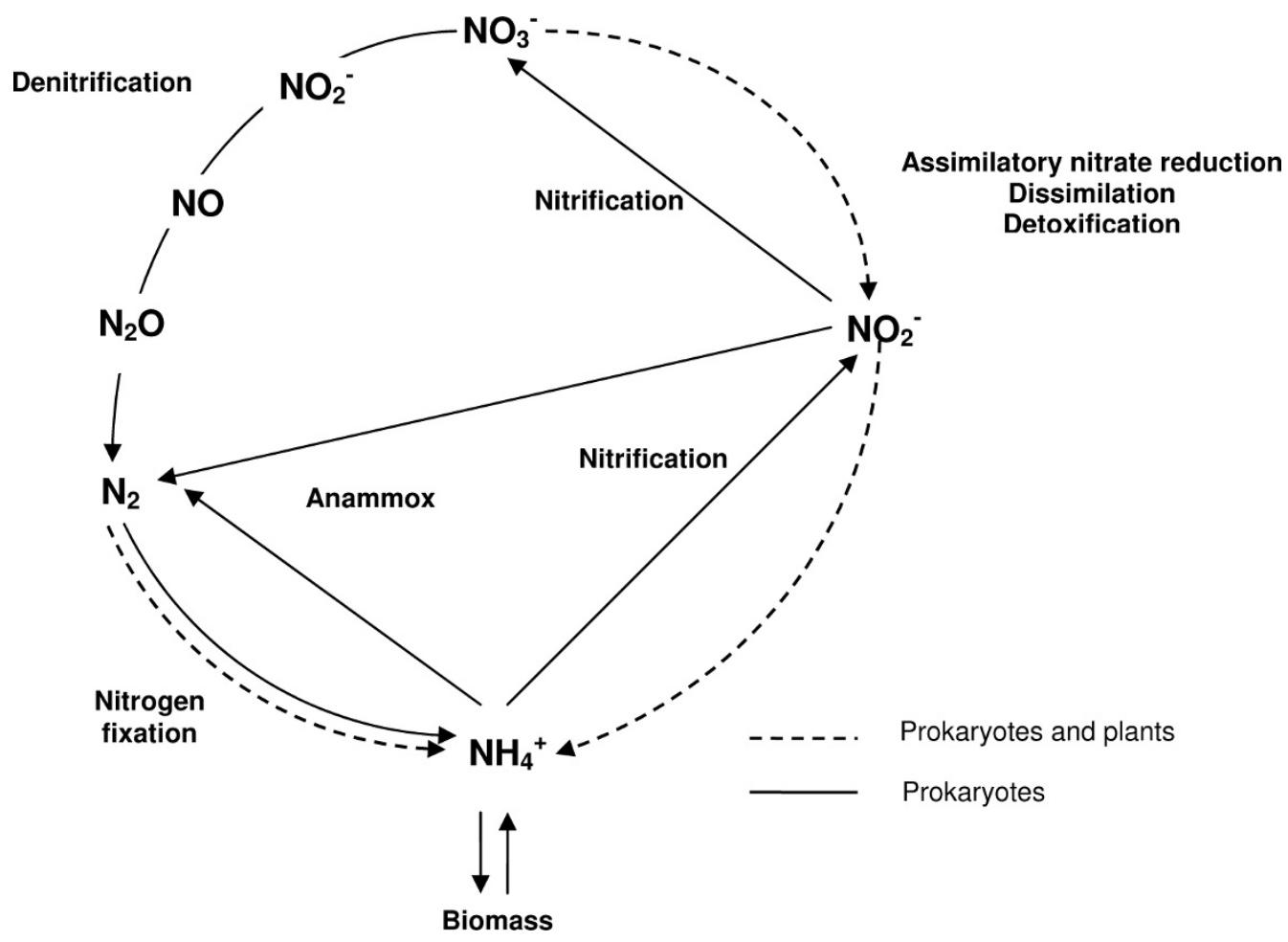

\section{Figure I}

$\mathrm{N}$-cycle scheme. $\mathrm{NO}_{3}^{-}$is used as nitrogen source for growth under aerobic conditions using an assimilatory $\mathrm{NO}_{3}^{-}$reductase, while it acts as an electron acceptor to eliminate excess of reductant power through dissimilatory $\mathrm{NO}_{3}{ }^{-}$reduction. Dissimilatory $\mathrm{NO}_{3}{ }^{-}$reduction, $\mathrm{NO}_{3}{ }^{-}$respiration or denitrification are often used equivalently in the literature. However, dissimilatory pathway makes reference to non-assimilatory reactions that are not directly coupled to generation of proton-motive force. In some Enterobacteriaceae, $\mathrm{NO}_{2}{ }^{-}$is reduced to $\mathrm{NH}_{4}{ }^{+}$which is then excreted; this process is known as $\mathrm{NO}_{3}-/ \mathrm{NO}_{2}^{-}$ammonification. Specialised organisms are able to oxidize either $\mathrm{NH}_{4}{ }^{+}$or $\mathrm{NO}_{2}$ - by using a pathway called nitrification, while other organisms such as some planctomycetes oxidize $\mathrm{NH}_{4}{ }^{+}$and utilize $\mathrm{NO}_{2}{ }^{-}$as respiratory electron acceptor in a pathway named anammox. Finally, (di)nitrogen fixation allows several bacteria and archaea to reduce $\mathrm{N}_{2}$ to $\mathrm{NH}_{4}^{+}$to provide $\mathrm{N}$-requirements.

living or symbiotic diazotrophic prokaryotes, assimilatory nitrate reduction is a property of many species of bacteria, fungi, algae, higher plants and Archaea. Nitrification and denitrification are redox processes involving nitrogen compounds to obtain metabolic energy. Nitrification consists of the oxidative conversion of ammonia to nitrite via hydroxylamine, and further oxidation of nitrite to nitrate [6]. On the other hand denitrification is a respiratory process (under anaerobic conditions) whereby nitrate is reduced to nitrite, $\mathrm{NO}, \mathrm{N}_{2} \mathrm{O}$ and $\mathrm{N}_{2}$. Ammonification is the dissimilatory reduction of nitrate to ammonia that does not serve the purpose of nitrogen autotrophy [7]. Anaerobic ammonium oxidation (Anammox) is a reaction that produces $\mathrm{N}_{2}$ by reducing nitrite and oxidizing ammonium. This process, recently described, seems to be of ecological importance in marine environments [8].

Some of the compounds produced thanks to N-cycle reactions could affect life in different ways. Related to this, nitrous oxide $\left(\mathrm{N}_{2} \mathrm{O}\right)$ and nitric oxide (NO) have impact on the atmosphere: i) $\mathrm{N}_{2} \mathrm{O}$ is a more potent greenhouse gas than $\mathrm{CO}_{2}$ contributing to global warming, ii) in the stratosphere, $\mathrm{N}_{2} \mathrm{O}$ and $\mathrm{NO}$ destroy the ozone layer that protects organisms against UV light, iii) NO can be chemically oxidized to $\mathrm{NO}_{2}$, which is further hydrated to $\mathrm{HNO}_{2}$ and $\mathrm{HNO}_{3}$ (components of the acid rain). Besides, it is very important to note that when fertilizers are used at high concentrations or are not used by plants or microorganisms, products such as $\mathrm{NO}_{3}{ }^{-}$or $\mathrm{NO}_{2}$ - can enter the aquifers $[9,10]$. The consumption of drinking water containing high $\mathrm{NO}_{3}{ }^{-}$and $\mathrm{NO}_{2}{ }^{-}$concentrations causes human health concerns because $\mathrm{NO}_{2}$ - interacts with haemoglobin. This results in the inhibition of the oxygen transport through the human body which is known as metahemoglobinemia. It has also been demonstrated that different kinds of gastric cancer are associated with the consumption of water with high nitrate and nitrite concentrations [11]. 
Although the $\mathrm{N}$-cycle is well characterised in bacteria from physiological, biochemical and genetic points of view, there are few studies centred on this metabolic pathway in halophilic archaea. These studies, carried out with several Haloferax, Haloarcula and Halobacterium species, are mainly focused on denitrification [12-17]. Related to this, $H f x$ mediterranei is the only halophilic archaeon from which assimilatory pathway has been analysed in detail [18-22]. Recent studies on the respiratory nitrate pathway have revealed that respiratory nitrate reductases from $H f x$ mediterranei or Har marismortui are facing on the positive face of the membrane, instead of having the active site facing the cytoplasm as it has been reported for most of the bacterial nitrate reductases $[16,23]$. This review covers the current knowledge on $\mathrm{N}$-cycle in $\mathrm{H} f x$ mediterranei with the objective to shed light on the haloarchaeal nitrogen metabolism and its implications on several environmental issues.

\section{Assimilatory nitrate reduction in Hfx mediterranei}

Nitrate assimilation is one of the main processes of the $\mathrm{N}$ cycle, and it allows the use of $\mathrm{NO}_{3}{ }^{-}$as $\mathrm{N}$ source for growth. In silico studies have revealed that genes encoding the proteins involved in nitrate assimilation have been found in the genomes of the two major Archaea subgroups: crenarchaeota and euryarchaeota [24]. However, physiological and biochemical characterisation of $\mathrm{NO}_{3}{ }^{-}$assimilation have been performed only in Hfx mediterranei at the time of writing this review.

In the assimilatory nitrate reduction, first $\mathrm{NO}_{3}$ - is incorporated into the cells by high-affinity transporters and further reduced to $\mathrm{NH}_{4}{ }^{+}$, via $\mathrm{NO}_{2}^{-}$, by two sequential reduction reactions catalysed by assimilatory nitrate reductase (Nas; EC 1.6.6.2) and assimilatory nitrite reductase ( $\mathrm{Nir}$; EC 1.7.7.1). The $\mathrm{NH}_{4}{ }^{+}$produced is incorporated into carbon skeletons by the glutamine synthetase/glutamate synthase pathway (GS-GOGAT; EC 6.3.1.2, EC 1.4.7.1, respectively) or via glutamate dehydrogenase (GDH; EC 1.4.1.2). The GS/GOGAT pathway is particularly important because it allows ammonia assimilation into L-Glu at low intracellular ammonia concentrations and it seems that it efficiently substitutes the other glutamate biosynthetic reaction (GDH) in these conditions. Nevertheless, in some bacteria it has been found that GDH is not significantly affected by the type or the concentration of the nitrogen source supplied [25].

\section{$\mathrm{NO}_{3}$ - uptake}

In bacteria, the genes coding for the regulatory and structural proteins required for $\mathrm{NO}_{3}$ - uptake and reduction are, in most cases, clustered [26] and frequently $\mathrm{NO}_{3}{ }^{-}$is transported into the cells by an active system. Two types of nitrate transporters are involved in prokaryotic assimilatory nitrate reduction: ATP-dependent ABC transporters (composed of an integral membrane subunit, a cytoplasmic ATP-binding component and a periplasmic substratebinding protein) and the monomeric NarK-type transporters belonging to the major facilitator superfamily (MFS-type permease), which depend on proton-motive force. $\mathrm{ABC}$ transporters form a widespread protein family present in Archaea, Bacteria and Eukarya. In the haloarchaeal $H f x$ volcanii, three genomic regions containing genes coding for $\mathrm{ABC}$ transporters subunits involved in nitrate respiration were characterised [27], but there is not any evidence of its participation in the assimilatory process. These genes have been characterised from genomic libraries contructed using several nitrate respiration-deficient $H f x$ volcanii mutants. Most archaea with putative $\mathrm{ABC}$ nitrate transporters seem to contain respiratory nitrate reductases rather than assimilatory nitrate reductases.

Within the bacterial NarK-like transporters there are two subgroups: NarK1 (proton: nitrate symporter that allows initiation of nitrate respiration) and NarK2 (nitrate: nitrite antiporter required for maintenance of a steadystate rate) [28]. Some of these proteins are involved in $\mathrm{NO}_{3}{ }^{-} / \mathrm{NO}_{2}{ }^{-}$exchange rather than simply in the uptake of one of these anions, but the mechanism of the transport has not been determined for any of these bacterial MFS importers. It has been suggested that bacterial nitrate assimilation usually requires ATP-dependent $\mathrm{ABC}$ nitrate transporters whereas nitrate respiration is associated with proton-motive-force driven NarK transporters [28].

Database comparisons of the genes involved in the assimilation of nitrate in $H f x$ mediterranei revealed that $n a s B$ gene (Q703N4) encodes a $\mathrm{NO}_{3}{ }^{-}$transporter with a molecular mass around $46.1 \mathrm{kDa}$. This transporter is a membrane protein with 12 potential $\alpha$ helices and is most closely related with the NarK1 type of transporters. The best fits of nasB gene were with bacterial homologues, such as Thermus thermophilus, Paracoccus halodenitrificans and Pseudomonas aeruginosa [20]. nasB from Hfx mediterra$n e i$ is the first NarK transporter reported to date in Archaea, which suggests that the NarK group could be involved in the assimilatory process and it is not exclusive to Bacteria and Eukarya as it had originally been suggested.

\section{Nitrate and nitrite assimilation}

When nitrate is imported into Hfx mediterranei cells, it is reduced to nitrite by the ferredoxin dependent assimilatory nitrate reductase (Nas). In general, Nas are cytoplasmic enzymes that catalyse the two-electron reduction of $\mathrm{NO}_{3}{ }^{-}$to $\mathrm{NO}_{2}{ }^{-}$. They are repressed by ammonium and use either NADH or ferredoxin as physiological electron donors, although some use flavodoxin instead of ferredoxin. Fd-Nas are usually monomeric enzymes while NADH-dependent Nas have been described as het- 
erodimeric proteins [29]. Both of them are structurally and functionally different from the dissimilatory periplasmic nitrate reductases (Nap; EC 1.7.99.4) and the respiratory membrane-bound nitrate reductases (Nar; EC 1.7.99.4) present in many prokaryotes. On the basis of the gene sequence and the UV-Vis spectra, Hfx mediterranei ferredoxin-dependent Nas (Q703N5) contains a Mo-bismolybdopterin guanine dinucleotide cofactor (Mo-bisMGD) and one [4Fe-4S] cluster $[19,20]$. In this case, the electrons probably flow from the [2Fe-2S] cluster-containing ferredoxin (which is a negative redox potential electron donor) to the [4Fe-4S] cluster and from this centre to the Mo-cofactor for the reduction of $\mathrm{NO}_{3}{ }^{-}$(Fig. 2). $\mathrm{Hfx}$ mediterranei Nas was first described as a dimeric enzyme [19]. Nevertheless, recent studies have revealed that this enzyme is a monomeric protein with a molecular mass around $75 \mathrm{kDa}$ and it is most closely related with monomeric bacterial ferredoxin-dependent Nas proteins [20]. The highest similarity scores were to the Nas proteins of Pseudomonas aeruginosa, Xanthomonas campestris and Synechococcus elongates [20]. The comparison with the products of the putative assimilatory nitrate reductase genes from other archaea showed that there was only a low overall similarity between these and assimilatory nitrate reductase from Hfx mediterranei, with conserved residues pre- dominantly being associated with the cofactor binding sites. Nas kinetic parameters have been obtained that suggest that the $K_{m}$ for nitrate is around $0.95 \mathrm{mM}$ and the enzyme has maximum activity at $80^{\circ} \mathrm{C}$ in $3.1 \mathrm{M} \mathrm{NaCl}$, but $60^{\circ} \mathrm{C}$ in $1.3 \mathrm{M} \mathrm{NaCl}$. Nas can receive electron from methylviologen and benzylviologen but not $\mathrm{NAD}(\mathrm{P}) \mathrm{H}$. Nas activity is induced by nitrate and repressed by ammonium, as described for bacterial Nas [20,22]. Up to now, this is the only Nas purified and characterised from a biochemical and genetical point of view from haloarchaea.

Nitrite produced by Nas is reduced to ammonium by ferredoxin dependent assimilatory nitrite reductase (Q703N2) that catalyses the six-electron reduction of $\mathrm{NO}_{2}{ }^{-}$. As it has been described above for Nas, assimilatory nitrite reductases are classified into two groups according to the electron donor specificity: Fd-dependent Nir (described from eukaryotic and prokaryotic photosynthetic organisms) and NAD(P)H-dependent Nir (present in fungi and most heterotrophic bacteria). Fd-Nirs are cytoplasmic monomeric proteins with molecular mass around $55 \mathrm{kDa}$. They contain a siroheme and a [4Fe-4S] cluster as redox centres. The electrons flow from ferredoxin to Nir in a similar way to that described for Nas (electrons from the [2Fe-2S] cluster-containing ferredoxin

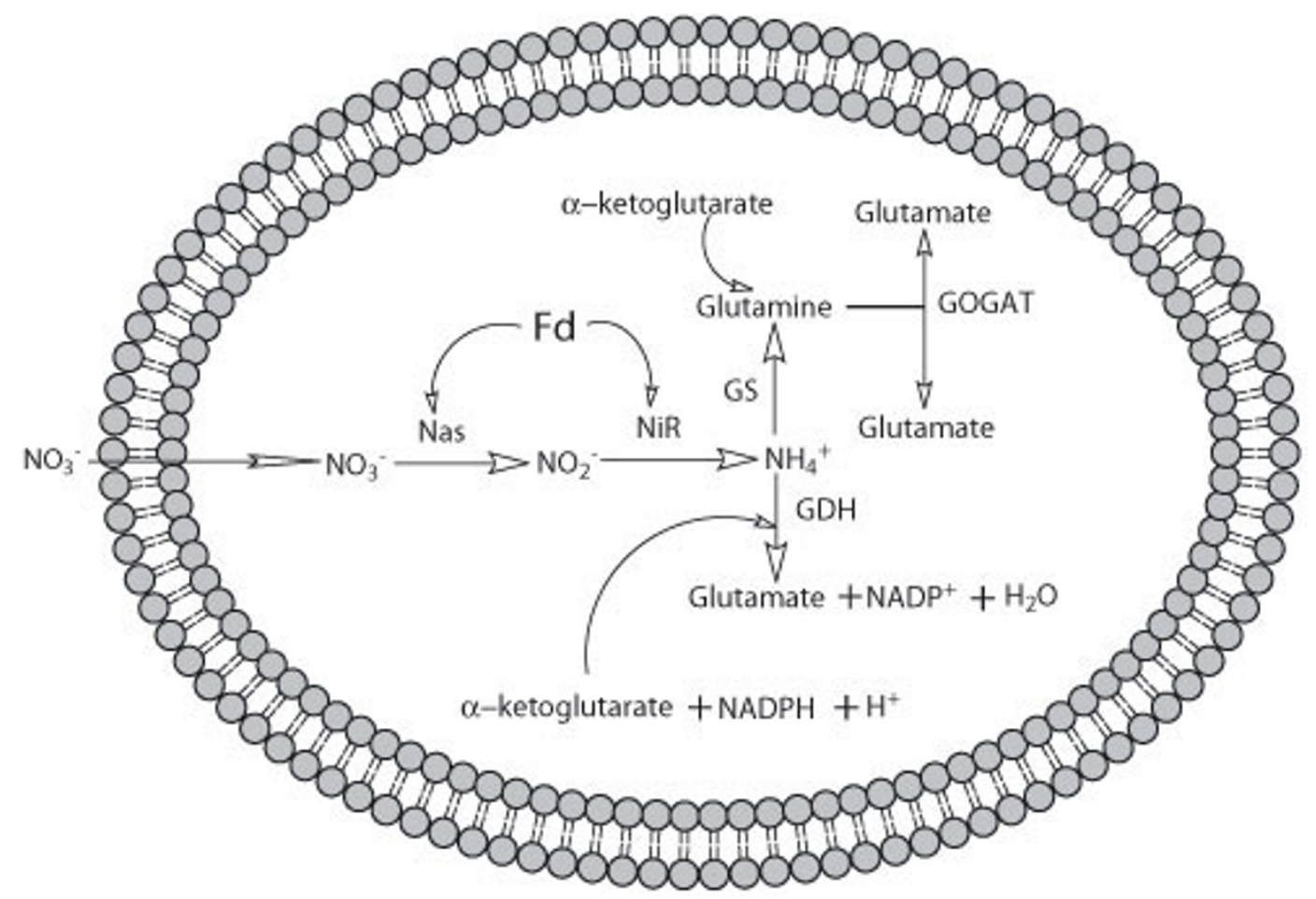

Figure 2

Assimilatory nitrate reduction in $H f x$ mediterranei. All the enzymes presented in the figure have been purified and characterised except glutamate synthase. Nas: assimilatory nitrate reductase; NiR: assimilatory nitrite reductase; Fd: Ferredoxin; GDH: glutamate dehydrogenase; GS: glutamine synthetase; GOGAT: glutamate synthase. 
are transferred to the [4Fe-4S] cluster and from this centre to the siroheme for the reduction of nitrite). On the other hand, NADH-Nirs consist of two subunits, and contain non covalently bound FAD, a [4Fe- $4 \mathrm{~S}]$ cluster, and siroheme as prosthetic groups. The assimilatory nitrite reductase purified from Hfx mediterranei, the first one purified from this kind of microorganisms, is a $66 \mathrm{kDa}$ monomer that shows a strong sequence similarity with known ferredoxin-dependent nitrite reductases, such as those of Synechocystis sp., Plectonema boryanum and Synechococcus elongatus. Some of its biochemical properties have been analysed in detail showing that it has a $K_{m}$ for nitrite of 8.6 $\mathrm{mM}$, and maximal activity at $60^{\circ} \mathrm{C}$ in presence of $3.3 \mathrm{M}$ $\mathrm{NaCl}$. Like most of the bacterial assimilatory nitrite reductases described so far, the Hfx mediterranei Nir contains siroheme and Fe-S centres $[18,20]$.

The Hfx mediterranei ferredoxin involved in the electron transfer to Nas or Nir is a small protein $(\mathrm{Mr} \approx 21 \mathrm{kDa}$ on SDS-PAGE) $[30,31]$ that shows UV-Vis, NMR and EPR spectra similar to those described from plant and bacteria ferredoxins containing one $[2 \mathrm{Fe}-2 \mathrm{~S}]$ cluster. The electron paramagnetic resonance spectrum of the reduced form of the protein displayed a rhombic signal, with $\mathrm{gx}=1.91$, gy $=1.98, \mathrm{gz}=2.07$. UV-visible spectropotentiometric analysis determined a midpoint redox potential for the [2Fe$2 \mathrm{~S}]^{2+/ 1+}$ transition of around $-285 \mathrm{mV}$ vs. SHE that was independent of salt concentration. Significantly, this ferredoxin was shown to be a highly thermostable protein. It was stable up to $60^{\circ} \mathrm{C}$ in a low-salt $(0.2 \mathrm{M})$ medium and this increased to $80^{\circ} \mathrm{C}$ in a high-salt $(4 \mathrm{M})$ medium. Ferredoxins from other halophilic archaea such as Hbt halobium [32], Har marismortui [33], and Har japonica [34] have been purified and characterised and in all cases they contain a [2Fe-2S] cluster. However, although all of them belong to the plant type differences between these two groups have been emphasised [32].

\section{Ammonium transport and assimilation}

When ammonium is the nitrogen source for growth, the first step is its across biological membranes facilitated by the ammonium transporter (Amt). Amt transporters are integral membrane proteins that allow the ammonium and methylammonium uptake. This kind of transporter is well characterised in Bacteria and Eukarya domains, however it still remains quite unknown in Archaea, in fact only the Amt from Archaeoglobus fulgidus [35] has been studied to date from the Archaea domain. Recent structural information on two prokaryotic Amt proteins has significantly contributed to our understanding of these transporters [36]. The mechanisms involved in the ammonium uptake in Hfx mediterranei are unknown at the time of writing this paper. However, the processes related to the assimilation of ammonium produced by Nir in this archaea have been recently described in our group [22].
Glutamine synthetase-glutamate synthase (GS-GOGAT) and glutamate dehydrogenase (GDH) are the main pathways for ammonium assimilation in several microorganisms including $H f x$ mediterranei. The first pathway requires ATP but has high affinity for ammonium, whereas GDH does not consume ATP but is less effective in cells growing in N-limited conditions. These enzymes are present in all three domains of life.

Glutamine synthetase (GS), the first enzyme of the GS/ GOGAT pathway, has been extensively studied at both biochemical and molecular levels in prokaryotes, mammals and some methanogenic and hyperthermophilic archaea $[37,38]$. This enzyme plays a dual role by providing glutamine for biosynthesis and by assimilating ammonium in collaboration with glutamate synthase. In summary, three types of GS have been described based on the molecular size and the number of subunits. GSI is a dodecameric protein with subunit ranging between 44 and $60 \mathrm{kDa}$, and is usually found among several groups of bacteria and archaea $[39,40]$. GSII is common in eukaryotes and a few soil-dwelling bacteria as an octameric enzyme composed of subunits ranging between 35 and 50 $\mathrm{kDa}$ [41]. Finally, GSIII has been characterised from cyanobacteria and two anaerobic bacteria as a hexameric enzyme composed of a $75 \mathrm{kDa}$ subunits [42].

Few analyses have been carried out with GS from members of Archaea, and just two are from GS from haloarchaea $[21,43]$; these enzymes, purified from $H f x$ mediterranei and $\mathrm{Hbt}$ salinarium are octamers belonging to the GS type II [21,43]. However, a few GSs described from methanogenic or hyperthermophilic archaea are dodecamers of about $600 \mathrm{kDa}$. So, GS from haloarchaea exhibits typical properties of GS from eukaryotes and soil bacteria species. This fact supports the hypothesis that some members of Archaea are quite like eukaryotic organisms because both of them share similar properties at physiological and metabolic levels [44]. The results obtained from Hfx mediterranei suggest that GS from this haloarchaea could allow the assimilation of the ammonium produced by assimilatory nitrite reductase $[21,22]$, while GDH would allow the assimilation of ammonium when this nitrogen source is present in the culture media at high concentrations. The biochemical characterisation of $H f x$ mediterranei GS shows an optimum $\mathrm{pH}$ value for activity around 8 . Either in the presence of $\mathrm{NaCl}$ or $\mathrm{KCl}$, the maximum stability was found at the highest salt concentration described by us $(3.5 \mathrm{M}$ and $2.5 \mathrm{M}$, respectively). The $K_{m}$ value for ADP could not be calculated for the transferase activity, as all concentrations analysed produced similar results $\left(K_{m}\right.$ around $\left.3.10 \pm 0.5 \mathrm{mM}\right)$. The apparent $K_{m}$ for $\mathrm{NH}_{2} \mathrm{OH}$, Gln, ATP and Glu were $10.5 \pm$ $3.5,25 \pm 1.8,0.30 \pm 0.08$ and $4.9 \pm 1.5 \mathrm{mM}$, respectively. These values are similar to those described in $\mathrm{Hbt}$ sali- 
narium GS and are in the range described for GS from different cyanobacteria [45] and Archaea [46]. GS activity decreased substantially in the presence of MSX (an irreversible inhibitor of bacterial GS) as it was described from other prokaryotic GS [22]. Studies about the effectiveness of different metal ions on the activity assay revealed that $\mathrm{Mn}^{2+}$ was the most effective ion for transferase activity as it was expected due to its essential role as a cofactor.

Glutamate synthase, the second enzyme of the GS/ GOGAT cycle, is an NADPH dependent enzyme in most of bacteria and it has two dissimilar enzyme subunits $\alpha$ and $\beta$ that forms the $\alpha \beta$ active protomer which contains one FAD, one FMN, and three different [Fe-S] centres: one [3Fe-4S] cluster and two [4Fe-4S] centres [47]. The plant type GOGAT is dependent on reduced ferredoxin as physiological electron donor and it is formed by a single polypeptide chain similar in sequence and cofactor content (one FMN, and one [3Fe-4S] cluster) to the $\alpha$ subunit of the bacterial enzyme.

Whether Archaea contain a bacterial type, a plant type or a fourth class still needs to be verified. Methanococcus jannaschii genome sequencing first revealed the presence of one ORF encoding a 490 residues polypeptide that appears to be formed by an $\mathrm{N}$-terminal domain containing the Cys-signature typical of two bacterial ferredoxins [4Fe-4S] clusters followed by a polypeptide mapping on the synthase domain of NADPH-GltS $\alpha$ subunit [47]. A similar ORF has been found in A fulgidus and appears to be conserved in other Archaea and in Thermatogales as the result of lateral gene transfer. It has also been proposed that a fifth type of glutamate synthase may exist. An ORF encoding a $50 \mathrm{kDa}$ protein of Pyrococcus sp. KOD1 with significant sequence similarity to NADPH-GltS $\beta$ subunit has been found and it was assigned the gene name of glt $\mathrm{A}$ [47]. The analysis of the halophilic archaeal genomes sequenced suggested that in Har marismortui, Natronomonas pharaonis and Haloquadratum walsbyi there are open reading frames of about 1500 residues similar in sequence to the plant type ferredoxin dependent glutamate synthase and to the bacterial NADPH glutamate synthase $\alpha$ subunit, but there is not evidence of the presence of an open reading frame corresponding to a polypeptide similar to the bacterial NADPH glutamate synthase $\beta$ subunit. In $H f x$ mediterranei, we have detected activity of glutamate synthase with methylviologen as reducing agent in extracts from cells grown with ammonium starvation (data not published). Analysis of the gene sequence revealed a high degree of homology with ORFs of sequenced genomes of Fd-dependent glutamate synthases. The classification of archaeal glutamate synthase and particularly of haloarchaeal glutamate synthase stills needs to be verified by biochemical characterization.
As it has been cited before, Hfx mediterranei is able to assimilate ammonium via glutamate dehydrogenase (GDH) [48]. This is an important enzyme because it catalyses the interconvertion between 2-oxoglutarate and Lglutamate reversibly and plays a key role since it provides a link between carbon and nitrogen metabolism. Several studies have demonstrated that under nitrogen-sufficient conditions, GDH mainly catalyses glutamate production from 2-oxoglutarate and ammonium. However, under nitrogen-starvation conditions, GS produces glutamine from glutamate and ammonium, and glutamine is then converted to glutamate by GOGAT. The GS-GOGAT pathway is the major route for utilization of ammonium when ammonium is deficient [49] because GS has a much lower $K_{m}$ for ammonium than does GDH. However, in some bacteria it has been found that GDH is active under low ammonium conditions [25].

GDHs are classified into three groups according to their coenzyme specificity: NAD or NADP-specific and NAD(P)-non specific dependent GDH. Hfx mediterranei has at least two different GDHs: NADP-GDH and NADGDH $[48,50]$.

\section{Assimilatory nitrate pathway regulation in $\mathrm{Hfx}$ mediterranei}

In Hfx mediterranei a 6,720 bp genomic fragment was sequenced containing homologues of the nitrate assimilation genes nas $A B C$ and $D$, which code for assimilatory nitrate reductase (nasA, Q703N5), a nitrate transporter belonging to NarK group (nasB, Q703N4), cited above, a molybdopterin guanine dinucleotide biosynthesis protein (nasC, Q703N3) and an assimilatory nitrite reductase (nasD, Q703N2). RT-PCR studies demonstrated [21] that $n a s A B C$ are cotranscribed but nasD is transcribed as a monocistronic messenger which is a novel organization in comparison with bacterial nas operons where, in general, bacterial nitrite reductase gene is found within the nitrate reductase gene operon [51]. The location of Hfx mediterranei nitrite reductase gene outside of nas operon raises interesting questions regarding the regulation of nas $A B C$ and $n a s D$ in relation to the cellular demand for nitrogen assimilation. Both promoters show a good match to the archaeal consensus TATA box, and transcription factor B responsive element. Moreover, palindromic regions were identified that may be implicated in regulation. Taken together, both promoters could be controlled by common and different modulators.

In ammonium medium, transcription of nas $A B C$ or nas $D$ was not detected, but in minimal medium with nitrate both were transcribed, indicating that these genes were coding for a nitrate assimilation system. Moreover, nas$A B C$ mRNA was detected in minimal medium supplemented with nitrite, suggesting that the absence of 
ammonium was the effector of expression. The results obtained from physiological experiments were in agreement with those obtained from the analysis of the expression of nas $A$ and nasD genes, i.e, ammonium repressed the expression of the assimilatory genes. However, in the presence of nitrate or nitrite as nitrogen sources, nasA and $n a s D$ expression levels increased under different culture conditions. This mechanism is a general control, which responds to the availability of the preferred nitrogen source: ammonium.

In addition to the short-term inhibitory effect of ammonium on nitrate uptake, ammonium can exert a negative effect on nitrate assimilation by affecting the activity levels of the enzymes involved in the assimilatory pathway. This ammonium effect, which was described many years before in bacteria and cyanobacteria [52], requires a more prolonged time scale to be expressed. Results obtained from $H f x$ mediterranei suggest that ammonium also causes the same long-term effect on both assimilatory activities, Nas and NiR. In cyanobacteria, the simultaneous presence in the medium of nitrate and ammonium is equivalent to that of ammonium alone [52]. So, the regulatory pattern of the assimilatory pathway in $H f x$ mediterranei is similar to those described for halotolerant bacteria [49], bacteria [4] and cyanobacteria [52], i.e., ammonium represses nas gene expression and inhibits the nitrate assimilation pathway, wheras nitrate is an inducer of gene expression. Accordingly, it has been observed that in the presence of ammonium nitrate or ammonium nitrite, ammonium is preferentially consumed by Hfx mediterranei cells.

New strategies should be addressed in the next few years in order to elucidate the mechanisms and the proteins involved in the regulation of the assimilatory metabolic pathway in Hfx mediterranei.

\section{Denitrification}

Denitrification, the biological production of $\mathrm{NO}, \mathrm{N}_{2} \mathrm{O}$ and $\mathrm{N}_{2}$ gases from $\mathrm{NO}_{3}{ }^{-}$under anoxic conditions, is a key process that contributes to the nitrogen cycle of the Earth [53]. In this pathway, nitrate may be reduced to $\mathrm{N}_{2}$ thanks to the reactions catalysed by respiratory nitrate reductase, respiratory nitrite reductase, nitric oxide reductase and nitrous oxide reductase. Each of these enzymes is coupled to energy-conserving electron-transport pathways [54]. Denitrifying microorganisms are distributed among the three domains of the life: Archaea, Bacteria and Eukarya and are able to respire oxygen, indicating a close evolutionary relationship between the two processes, where denitrification has been considered so far the ancestor of aerobic respiration $[55,56]$. The ability to use nitrate as a terminal electron acceptor in energy metabolism is found in several halophilic and hyperthermophilic archaea: many of them can perform the entire denitrification proc- ess. However this process has only been partially described from biochemical or genetically point of views from some haloarchaea species (Halobacterium sp., Hfx mediterranei, Hfx denitrificans and Har marismortui).

\section{Nitrate reduction}

Membrane-bound nitrate reductase (Nar) is the enzyme involved in anaerobic nitrate respiration and denitrification, being negatively regulated by $\mathrm{O}_{2}$ and unaffected by ammonium. These enzymes are composed of a catalytic subunit that binds a complex organic cofactor [the bismolybdopterin guanine dinucleotide (bis-MGD) cofactor] (NarG) and an electron-transfer subunit with four iron-sulphur centres (NarH). In most of bacteria, this complex bound to a membrane dihaem $b$ quinol-oxidizing component (NarI). Nar enzymes have been purified from several denitrifying haloarchaea belonging to Haloferax and Haloarcula genera. In some cases such us $H f x$ denitrificans, Har marismortui and Hfx mediterranei, the enzyme has been purified as a heterodimeric protein composed of two subunits with molecular masses around 116, 117 , or $112 \mathrm{kDa}(\mathrm{Nar} \mathrm{G})$ and 60,47 or $61 \mathrm{kDa}(\mathrm{NarH})$, respectively [15]. In other species such as $H f x$ denitrificans [14] or Hfx volcanii [13], Nar has been described as a heterotrimeric (100, 61 and $31 \mathrm{kDa})$ protein. In $H f x$ mediterranei two different nitrate reductases involved in nonassimilatory processes have been reported: Nar (characterised in our group) and a dissimilatory nitrate reductase studied by Alvarez-Ossorio et al [12]. The last one seems to be a protein with higher molecular mass and most of its enzymatic properties are different to those described from the enzyme characterised in our laboratory [15], so it is possible to think that the enzyme purified by Alvarez, described as a dissimilatory protein, allows the dissipation of reducing power for redox balancing. This possible role should be addressed by physiological analysis.

The N-terminal region of Har marismortui and $H f x$ mediterranei NarG includes a typical twin-arginine signal peptide for protein translocation across the membrane by TAT export pathway (twin arginine-dependent translocase) [23], and both enzymes have activity in situ with both, membrane permeable benzylviologen and membraneimpermeable methylviologen, suggesting that the catalytic site is located on the outside of the membrane.

Therefore, based on subunit composition, subcellular location of the active site and nar gene organization, it can be concluded that archaeal Nars are a new type of enzyme with the active site facing the outside and anchored to the membrane by a cytochrome $b$ (as it has been proposed for Hfx mediterranei system) or stabilized by the lipid environment in the membrane as described for the P. aerophilum Nar [57]. This system could be an ancient respiratory nitrate reductase, although the nitrite formed could also 
be assimilated. The outside location of the catalytic site of NarG in the halophilic archaeal Nar has important bioenergetic implications because to be energy-conserving require the coupling of this process to a proton-motive complex [23], instead of the typical redox-loop mechanisms, the NarI subunit described in bacteria. On the other hand, it seems that an active nitrate-uptake system would not be required for respiratory nitrate reduction in archaea, thus increasing the energetic yield of the nitrate reduction process (Fig 3 ).

\section{Nitrite reduction}

Nitrite produced by Nar is reduced to NO by the respiratory nitrite reductases. This reaction also takes place under anoxic conditions and it is not as well known as nitrate respiration in haloarchaea. In bacteria two different respiratory nitrite reductases have been reported: the homotrimeric copper-containing enzyme (encoded by nirK) and the homodimeric cytochrome $\mathrm{cd}_{1}$-nitrite reductase (encoded by nirS). The haem-containing enzyme seems to be more common in prokarya members and it has been described from different bacteria such as many Pseudomonas and Paracoccus species. The enzymes containing $\mathrm{Cu}$ and haem never coexist within the same bacterial species [58]. Up to now, only two respiratory nitrite reductases have been characterised from a haloarchaea member; these are the enzymes from Har marismortui and Hfx deni- trificans, which contain two $\mathrm{Cu}$ centres, and in both cases, the protein is encoded by the nirK gene. It has been suggested that the physiological electron donor for this protein could be halocyanin, a blue Cu-protein present in some Archaea [59]. This issue should be also addressed in Hfx mediterranei.

\section{$\mathrm{NO}, \mathrm{N}_{2} \mathrm{O}, \mathrm{N}_{2}$ production}

Nitric oxide (NO), the product of the respiratory nitrite reductases, is a toxic compound that is reduced to $\mathrm{N}_{2} \mathrm{O}$ by nitric oxide reductases (Nor) immediately after it has been generated. Different Nor enzymes from fungal denitrifiers and denitrifying bacteria have been analysed. In some cases, Nor is a soluble monomeric enzyme belonging to the cytochrome P-450 family [60]. In other microorganisms, Nor has been described as a membrane complex of a $17 \mathrm{kDa}$ cytochrome $c$ and a $38 \mathrm{kDa}$ cytochrome $b$ with 12 transmembrane regions. This enzyme is known such as cNor. It is not clear which class of Nor evolved first and it would thus be informative to characterise some Nors from denitrifying Archaea [54]. With regard to halophilic archaea, there is evidence for the presence of Nor (from physiological and biochemical studies) only in Har marismortui and Hfx denitrificans [24].

The last step of denitrification, the reduction of $\mathrm{N}_{2} \mathrm{O}$ to $\mathrm{N}_{2}$, is of great environmental importance because it closes

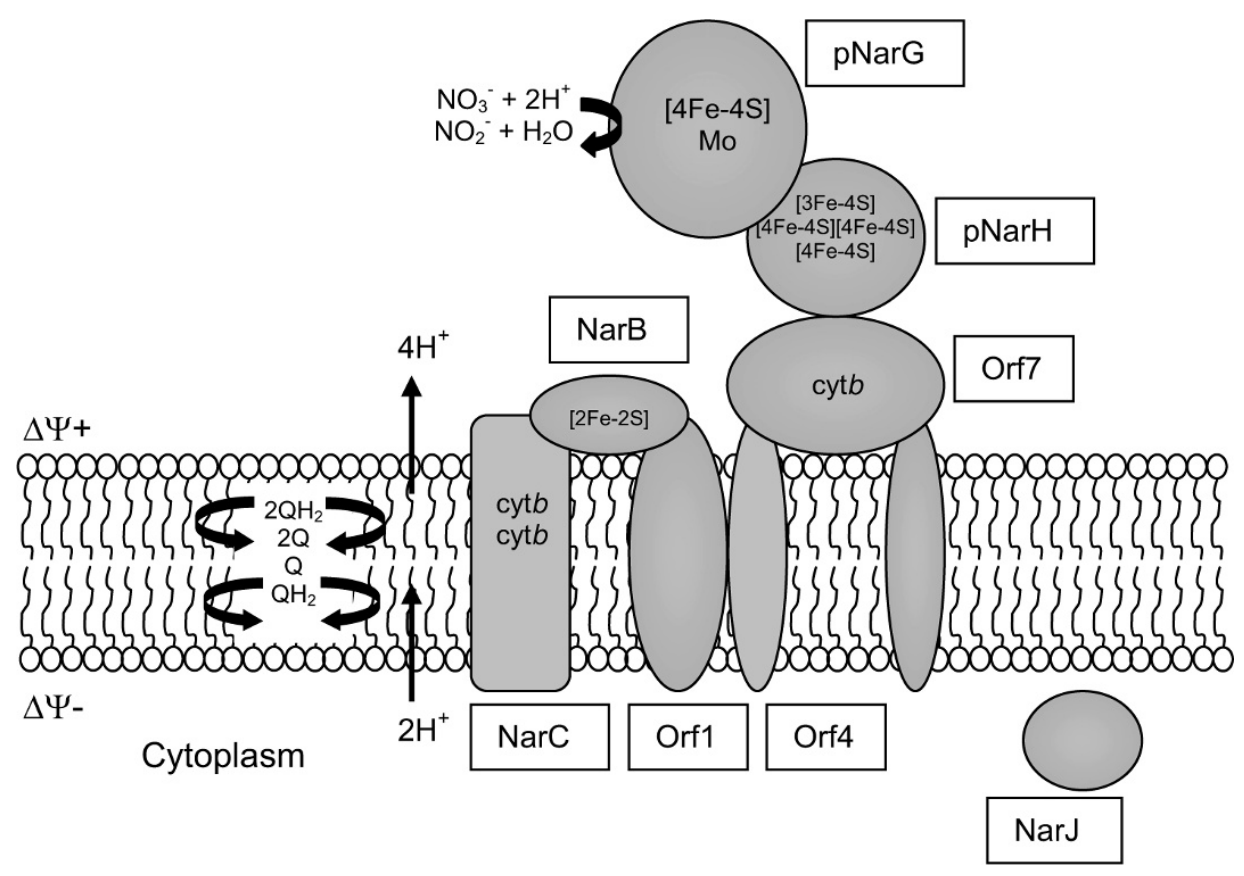

Figure 3

Orientation of the $\mathrm{NarGH}$ complex in $\mathrm{Hfx}$ mediterranei membranes. Informatic analysis of the nar operon as well as $\mathrm{NarGH}$ activity assays carried out with whole cells have revealed that archaeal Nars are a new type of enzyme with the active site facing the positive side of the membrane ( $\mathrm{pNarG}$ ). 
the $\mathrm{N}$-cycle. $\mathrm{N}_{2} \mathrm{O}$ is less toxic than $\mathrm{NO}$ or nitrite and the vast majority of microorganisms could manage without converting $\mathrm{N}_{2} \mathrm{O}$ into $\mathrm{N}_{2}$. However, most denitrifying bacteria contain nitrous oxide reductases (Nos) encoded by nos $Z$ gene which reduced $\mathrm{N}_{2} \mathrm{O}$ into $\mathrm{N}_{2}$. These enzymes are soluble periplasmic multicopper homodimers that receive electrons from cythorome $c$ or pseudoaurin [7].

In some halophilic archaea, such as Haloarcula it was described that the predominant gas species produced by denitrification is $\mathrm{N}_{2} \mathrm{O}$ [61]. However, a few years later, other studies suggested that, nitrite and $\mathrm{N}_{2}$ were produced during exponential growth. When Har marismortui culture enters stationary phase, dinitrogen production ceases, the concentration of nitrite in the medium rapidly decreases and nitrous oxide is accumulated. Other haloarchaea such as $H f x$ denitrificans are able to reduce $\mathrm{N}_{2} \mathrm{O}$ to $\mathrm{N}_{2}$, having a complete denitrification pathway [62].

The first of this kind of physiological experiment developed with $H f x$ mediterranei suggested that it produces dinitrogen during exponential growth accompanied of the accumulation of low quantities of nitrite and did not produce nitrous oxide [17]. However, recently, the production of $\mathrm{N}_{2} \mathrm{O}$ has been quantified from $H f x$ mediterranei cultures (Fig 4).

\section{Operon structure of denitrification genes in $\mathbf{H f x}$ mediterranei}

Denitrification and other anaerobic respiratory processes are alternative metabolic pathways developed by facultative microorganisms to obtain energy for growth under anoxic conditions, and therefore they are usually repressed by oxygen [63]. The control of the genes involved in this pathway is well studied in denitrifying bacteria. Although, the molecular basis of the regulatory networks of denitrification is beginning to emerge in halophilic archaea, they are still not well resolved. Molecules such us $\mathrm{O}_{2}, \mathrm{NO}_{3}{ }^{-}, \mathrm{NO}_{2}{ }^{-}$and $\mathrm{NO}$, act as signals to induce the regulation of this pathway. Related to this, more than one type of regulatory protein is involved in sensing the molecules cited above in bacteria: i) oxygen sensors (FixL and FNR) [64]; ii) nitrate and nitrite sensors (NarXL, NarPQ and NarR) [65]; iii) nitric oxide sensors (NNR and NoR); iv) redox sensors (Reg regulon) [66] and v) NiR and NosR proteins (essential proteins for expression and transcription of the nos and nir gene cluster) $[67,68]$.

There are only few in silico studies which reveal that potential regulators involved in bacterial nitrate reduction (cited above) are not present in the few archaeal genomes sequenced to date. This fact suggests that a novel regulatory system could operate in archaea. Some studies in methanogenic archaea demonstrated that Mo also regulates the expression of the genes required for archaeal molybdoproteins [69].

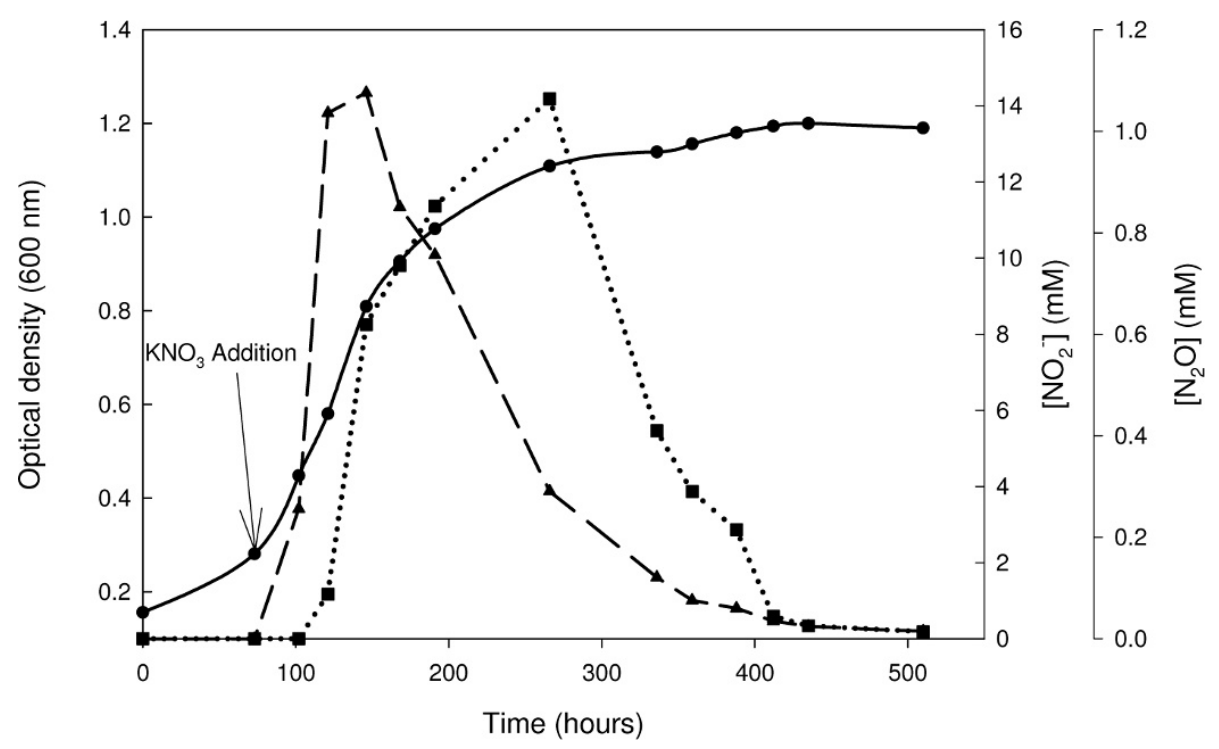

Figure 4

Nitrite and nitrous oxide production by $\mathrm{Hfx}$ mediterranei cells growing under anaerobic conditions as previously described [I5]. (O) Optical density $(600 \mathrm{~nm})$ vs. time (hours), ( 4$) \mathrm{NO}_{2}^{-}$production (mM) vs. time (hours), ( $\square$ ) $\mathrm{N}_{2} \mathrm{O}$ production (mM) vs. time (hours). 
In general, bacterial and archaeal respiratory nitrate systems also differ in the organization of the genes [70]. The main narGHJI operon organization is conserved in most bacteria; nevertheless halophilic archaea nar genes do not conserve this organization. In Har marismortui, for example, two small ORFs and a NarJ homologue are located downstream from the narGH genes, and putative genes encoding an iron-sulphur protein and a cytochrome $b$ are located upstream from narGH [16]. Similar organization has been found in Hfx mediterranei Nar system. In this case, the nar operon encodes eight open reading frames (ORF1, narB, narC, ORF4, narG, narH, ORF7 and narJ). ORF1 (Q703I0), ORF4 (Q703H7) and ORF7 (Q703H3) are open reading frames showing similarity with small proteins (molecular mass around $20 \mathrm{kDa}$ ) involved in electron transport. narB (Q703H9) codes for a 219amino-acid-residue Rieske iron-sulfur protein. The ORF 1, 4 and 7 and NarB are predicted to form a quinol-dependent electron transfer system that could be coupled to free energy transduction by a Q-cycle mechanism. narC (Q703H8) encodes a protein of 486 amino acid residues identified by databases searches as cytochrome- $b$ (narC). The narG (Q703H6) gene encodes a protein with 983 amino acid residues and is identified as a respiratory nitrate reductase catalytic subunit (narG). NarH protein has been identified as an electron transfer respiratory nitrate reductase subunit (narH, Q703H5)). The last ORF encodes a chaperonin-like protein (narJ, Q703H4) of 242 amino acid residues [15].

As the nar genes were present before the phylogenetic divergence of bacteria and archaea, it can be assumed that respiratory nitrate reductase played a key role in energy metabolism during pre-oxic times.

We used RT-PCR to determine the effect of anaerobic conditions and nitrate in the expression of the nar operon in $H f x$ mediterranei. In summary, regulation of nar genes occurs at transcriptional level, and is influenced by oxygen-limiting conditions and the presence of nitrate. No regulatory protein could be identified in the vicinity of the nar operon, but the presence of a set of palindromic sequences in the promoter suggests that the transcriptional regulation occurs via protein binding. No known regulatory sequence patterns have been identified, indicating that this transcriptional regulation could be novel in the denitrifier organisms.

\section{Hfx mediterranei role in bioremediation processes}

Denitrification is important process in agriculture where it results in the loss of nitrate fertilizers from fields and in waste-treatment processes where nitrate must be removed from waste waters before release into the environment. Nitrate and nitrite have important agricultural, environmental, and public health implications [4]. The manufac- turing of chemicals compounds (pesticides, herbicides, explosives, etc.) usually generates effluents containing complex mixtures of salts and nitrate or nitrite. The capacity of microorganisms to degrade organic pollutants is severely limited by their ability to survive or proliferate in these waste waters [71]. The increase of salinity and nitrate/nitrite concentrations in soils and ground waters in the last few decades has focused much attention on the physiological and molecular mechanisms involved in salt-stress tolerance and nitrate metabolism by microorganisms [72]. Microorganisms are in general sensitive to low nitrate and nitrite concentrations. The inhibitory effect of these nitrogen compounds is due to the extreme toxicity of nitrite and nitric oxide produced upon nitrate reduction as it has been mentioned before.

Physiological studies carried out with Hfx mediterranei have revealed that it is resistant to very high nitrate (up to $2 \mathrm{M}$ ) and nitrite (up to $50 \mathrm{mM}$ ) concentrations (unpublished data). The nitrite concentration present in the cultures employed is one of the highest yet described for a prokaryotic microorganism. The nitrite present in the culture medium was removed during the growth of Hfx mediterranei; in fact, at the final of the stationary phase of growth (OD $=2.2$ ), only $20 \%$ of the nitrite present in the culture was still present in media in which the initial concentration was around $50 \mathrm{mM}$. So it is possible to envisage that this haloarchaeon could be applied in water bioremediation processes with the purpose to repair the damage caused by the excessive use of fertilizers in agricultural activities. This application could be beneficial in regions such as Comunidad Valencia or Murcia (Spain), where the water tables contain high nitrate and nitrite concentrations due to fertilization practices [73].

\section{Abbreviations}

Nir: Assimilatory nitrite reductase; Nas: Assimilatory nitrate reductase; Nar: Respiratory nitrate reductase; NIR: Respiratory nitrite reductase; Nor: Nitric oxide reductase; Nos: Nitrous oxide reductase; GS: Glutamine synthetase; GOGAT: Glutamate synthase; GDH: Glutamate dehydrogenase; SHE: Standard hydrogen electrode.

\section{Acknowledgements}

This work was funded in part by research grants from the MEC Spain (BIO2005-0899I-C02-0I), Generalitat Valenciana (GRUPOS04/72 and GV04B/55I). R.M.M.E. was supported by short-term fellowships (post-doc stay in DJR's Laboratory, Norwich) from FEBS, COST Action 856 and Generalitat Valenciana. DJR is a Royal Society Wolfson Foundation merit award holder.

\section{References}

I. Hageman RH, Redd AJ: Nitrate reductase from higher plants. Methods Enzymol 1980, 69:270-28I.

2. Solomonson LP, Vennesland B: Properties of a nitrite reductase of Chlorella. Biochim Biophys Acta 1972, 267:544-557. 
3. Sengupta S, Shaila MS, Rao GR: Purification and characterization of assimilatory nitrite reductase from Candida utilis. Biochem J 1996, 3 I 7:147-155.

4. Moreno-Vivián C, Cabello P, Martínez-Luque M, Blasco R, Castillo F: Prokaryotic nitrate reduction: molecular properties and functional distinction among bacterial nitrate reductases. J Bacteriol 1999, I 8 I:6573-6584.

5. Richardson DJ, Watmough N: Inorganic nitrogen metabolism in bacteria. Curr Opin Chem Biol 1999, 3:207-219.

6. Costa E, Pérez J, Kreft JU: Why is metabolic labour divided in nitrification? Trends Microbiol 2006, 14:213-219.

7. Zumft WG: Cell biology and molecular basis of denitrification. Microbiol Mol Biol Rev 1997, 61:533-6I6.

8. Graaf AA van de, Mulder A, de Bruijn P, Jetten MS, Robertson LA Kuenen JG: Anaerobic oxidation of ammonium is a biologically mediated process. Appl Environ Microbiol 1995, 6I:I246-|25I.

9. Hansen J, Sato M: Greenhouse gas growth rates. Proc Natl Acad Sci USA 2004, 101:16109-16114.

10. Dyominov IG, Zadorozhny AM: Greenhouse gases and recovery of the Earth's ozone layer. Adv Space Res 2005, 35:I369-I374.

I I. Fewtrell L: Drinking-water nitrate, methemoglobinemia, and global burden of disease: a discussion. Environ Health Perspect 2004, I | 2: 1 37|- | 374

12. Alvarez-Ossorio MC, Muriana FJG, de la Rosa FF, Relimpio AM: Purification and characterization of nitrate reductase from the halophile archaebacterium Haloferax mediterranei. Z Naturforsch 1992, 47C:670-676.

13. Bickel-Sandkötter S, Ufer M: Properties of a dissimilatory nitrate reductase from the halophilic archaeon Haloferax volcanii. Z Naturforsch 1995, 50C:365-372.

14. Hochstein LI, Lang F: Purification and properties of a dissimilatory nitrate reductase from Haloferax denitrificans. Arch Biochem Biophys 1991, 288:380-385.

I5. Lledó B, Martínez-Espinosa RM, Marhuenda-Egea FC, Bonete MJ: Respiratory nitrate reductase from haloarchaeon Haloferax mediterranei: biochemical and genetic analysis. Biochim Biophys Acta 2004, I 674:50-59.

16. Yoshimatsu K, Iwasaki T, Fujiwara T: Sequence and electron paramagnetic resonance analyses of nitrate reductase $\mathrm{NarGH}$ from a denitrifying halophilic euryarchaeote Haloarcula marismortui. FEBS Lett 2002, 5 | 6: | 45-150.

17. Mancinelli RL, Hochstein LI: The occurrence of denitrification in extremely halophilic bacteria. FEMS Microbiol Lett 1986 35:55-58.

18. Martínez-Espinosa RM, Marhuenda-Egea FC, Bonete MJ: Purification and characterisation of a possible assimilatory nitrite reductase from the halophile archaeon Haloferax mediterranei. FEMS Microbiol Lett 2001, 196: I I3-I I8.

19. Martínez-Espinosa RM, Marhuenda-Egea FC, Bonete MJ: Assimilatory nitrate reductase from the haloarchaeon Haloferax mediterranei: purification and characterisation. FEMS Microbiol Lett 200I, 204:381-385.

20. Lledó B, Marhuenda-Egea FC, Martínez-Espinosa RM, Bonete MJ: Identification and transcriptional analysis of nitrate assimilation genes in the halophilic archaeon Haloferax mediterranei. Gene 2005, 36 I:80-88.

21. Martínez-Espinosa RM, Esclapez J, Bautista V, Bonete MJ: An octameric prokaryotic glutamine synthetase from the haloar chaeon Haloferax mediterranei. FEMS Microbiol Lett 2006, 264: $110-116$.

22. Martínez-Espinosa RM, Lledó B, Marhuenda-Egea FC, Bonete MJ: The effect of ammonium on assimilatory nitrate reduction in the haloarchaeon Haloferax mediterranei. Extremophiles 2007, I I:759-767.

23. Martinez-Espinosa RM, Dridge EJ, Bonete MJ, Butt JN, Butler CS, Sargent F, Richardson DJ: Look on the positive side! The orientation, identification and bioenergetics of 'Archaeal' membrane-bound nitrate reductases. FEMS Microbiol Lett 2007 276: I29-139.

24. Cabello $\mathrm{P}$, Roldán MD, Moreno-Vivián C: Nitrate reduction and the nitrogen cycle in archaea. Microbiology 2004, I 50:3527-3546.

25. Ertan $\mathrm{H}$ : The effect of various culture conditions on the levels of ammonia assimilatory enzymes of Corynebacterium callunae. Arch Microbiol I992, I 58:42-47.
26. Moreno-Vivián C, Flores E: Nitrate assimilation in Bacteria. In Biology of the nitrogen cycle Edited by: Bothe H, Ferguson SF, Newton WE. Elsevier BV; 2007:263-282.

27. Wanner C, Soppa J: Genetic Identification of three ABC transporters as essential elements for nitrate respiration in Haloferax volcanii. Genetics 1999, I52:|4|7-1428.

28. Wood NJ, Alizadeh T, Richardson DJ, Ferguson SJ, Moir JW: Two domains of a dual-function NarK protein are required for nitrate uptake, the first step of denitrification in Paracoccus pantotrophus. Mol Microbiol 2002, 44: I57-I70.

29. Richardson DJ, Berks BC, Russell DA, Spiro S, Taylor CJ: Functional, biochemical and genetic diversity of prokaryotic nitrate reductases. Cell Mol Life Sci 200I, 58(2):I65-I78.

30. Martínez-Espinosa RM, Marhuenda-Egea FC, Donaire A, Bonete MJ: NMR studies of a ferredoxin from Haloferax mediterranei and its physiological role in nitrate assimilatory pathway. Biochim Biophys Acta 2003, I 623:47-5I.

3I. Martínez-Espinosa RM, Richardson DJ, Butt JN, Bonete MJ: Spectopotentiometric properties and salt-dependent thermotolerance of a [2Fe-2S] ferredoxin-involved nitrate assimilation in Haloferax mediterranei. FEMS Microbiol Lett 2007, 277:50-55.

32. Kerscher L, Oesterhelt D, Cammack R, O'Hall D: A new plant-type ferredoxin from halobacteria. Eur J Biochem 1976, 7 I:I01-107.

33. Werber MM, Mevarech M: Purification and characterization of a highly acidic 2Fe-ferredoxin from Halobacterium of the Dead Sea. Arch Biochem Biophys 1978, 187:447-456.

34. Sugimori D, Ichimata T, Ikeda A, Nakamura S: Purification and characterization of a ferredoxin from Haloarcula japonica strain TR-I. BioMetals 2000, I3:23-28.

35. Andrade SL, Dickmanns A, Ficner R, Einsle O: Expression, purification and crystallization of the ammonium transporter AmtI from Archaeoglobus fulgidus. Acta Crystallogr Sect F Struct Biol Cryst Commun 2005, 61:86I-863.

36. Andrade SL, Einsle O: The Amt/Mep/Rh family of ammonium transport proteins. Mol Membr Biol 2007, 24:357-365.

37. Reitzer L: Nitrogen assimilation and global regulation in Escherichia coli. Annu Rev Microbiol 2003, 57:155-176.

38. Adul Rahman RN, Jongsareejit B, Fujiwara S, Imanaka T: Characterization of recombinant glutamine synthetase from the hyperthermophilic archaeon Pyrococcus sp. strain KODI. Appl Environ Microbiol 1997, 63:2472-2476.

39. Robertson DL, Alberte RS: Isolation and characterization of glutamine synthetase from the marine diatom Skeletonema costatum. Plant Physiol 1996, I I I: I I69- I I75.

40. Brown JR, Masuchi Y, Robb FT, Doolittle WF: Evolutionary relationships of bacterial and archaeal glutamine synthetase genes. J Mol Evol 1994, 38:566-576.

4I. Kumada Y, Benson DR, Hillemann D, Hosted TJ, Rochefort DA Thompson CJ, Wohlleben W, Tateno Y: Evolution of the glutamine synthetase gene, one of the oldest existing and functioning genes. Proc Natl Acad Sci USA 1993, 90:3009-30 I 3.

42. Reyes JC, Florencio FJ: A mutant lacking the glutamine synthetase gene $(g \ln A)$ is impaired in the regulation of the nitrate assimilation system in the cyanobacterium Synechocystis sp. strain PCC 6803. J Bacteriol 1994, I 76:75 I6-7523.

43. Manitz B, Holldorf AW: Purification and properties of glutamine synthetase from the archaebacterium Halobacterium salinarium. Arch Microbiol 1993, I 59:90-97.

44. Woese CR: On the evolution of cells. Proc Natl Acad Sci USA 2002 99:8742-8747.

45. El Alaoui S, Díez J, Toribio F, Gómez-Baena G, Dufresne A, GarcíaFernández JM: Glutamine synthetase from the marine cyanobacteria Prochlorococcus spp: characterization, phylogeny and response to nutrient limitation. Environ Microbiol 2003, 5:4I2-423.

46. Bhatnagar L, Zeikus JG, Aubert JP: Purification and characterization of glutamine synthetase from the archaebacterium Methanobacterium ivanovi. J Bacteriol 1986, 165:638-643.

47. Vanoni MA, Curti B: Structure and function studies on the ironsulfur flavoenzyme glutamate synthase: an unexpectedly complex self-regulated enzyme. Arch Biochem Biophys 2005, 433: $|93-2| 1$.

48. Ferrer J, Pérez-Pomares F, Bonete MJ: NADP-glutamate dehydrogenase from the halophilic archaeon Haloferax mediterranei: enzyme purification, $\mathbf{N}$-terminal sequence and stability. FEMS Microbiol Lett 1996, 141:59-63. 
49. Hochman A, Nissany A, Amizur M: Nitrate reduction and assimilation by a moderately halophilic, halotolerant bacterium Bal. Biochim Biophys Acta 1987, 965:82-89.

50. Díaz S, Pérez-Pomares F, Pire C, Ferrer J, Bonete MJ: Gene cloning, heterologous overexpression and optimized refolding of the NAD-glutamate dehydrogenase from Haloferax mediterranei. Extremophiles 2006, I0:105-II5.

5I. Lin JT, Stewart V: Nitrate assimilation by bacteria. Adv Microb Physiol 1998, 39:330-379.

52. Flores E, Ramos JL, Herrero A, Guerrero MG: Nitrate assimilation by cyanobacteria. In Photosynthetic Prokaryotes: cell differentiation and function Edited by: Papageorgiu GC, Packer L. Elsevier Scientific Publishing Co., New York; 1983:363-387.

53. Ichiki H, Tanaka Y, Mochizuki K, Yoshimatsu K, Sakurai T, Fujiwara T: Purification, characterization, and genetic analysis of $\mathrm{Cu}$ containing dissimilatory nitrite reductase from a denitrifying halophilic archaeon, Haloarcula marismortui. J Bacteriol 2001 | 83:4|49-4|56.

54. Richardson DJ: Bacterial respiration: a flexible process for a changing environment. Microbiology 2000, |46:55|-57|.

55. Saraste M, Castresana J: Cytochrome oxidase evolved by tinkering with denitrification enzymes. FEBS Lett |994, 34 I:| -4.

56. Castresana J: Comparative genomics and bioenergetics. Biochim Biophys Acta 200I, I 506: |47- 162.

57. Afshar S, Johnson E, De Vries S, Schröder I: Properties of a thermostable nitrate reductase from the hyperthermophilic archaeon Pyrobaculum aerophilum. J Bacteriol 200I, | 83:549|-5495.

58. Rinaldo S, Cutruzzolà F: Nitrite reductases in denitification. In Biology of the nitrogen cycle Edited by: Bothe $\mathrm{H}$, Ferguson SJ, Newton WE. Elsevier BV; 2007:37-56.

59. Scharf B, Engelhard M: Halocyanin, an archaebacterial blue copper protein (type I) from Natronobacterium pharaonis. Biochemistry 1993, 32:12894-12900.

60. Nakahara K, Tanimoto T, Hatano K, Usuda K, Shoun H: Cytochrome P-450 55AI (P-450dNIR) acts as nitric oxide reductase employing NADH as the direct electron donor. I Biol Chem 1993, 268:8350-8355.

61. Werber MM, Mevarech M: Induction of a dissimilatory reduction pathway of nitrate in Halobacterium of the Dead Sea. A possible role for the 2 Fe-ferredoxin isolated from this organism. Arch Biochem Biophys 1978, I 86:60-65.

62. Tomlinson GA, Jahnke LL, Hochstein LI: Halobacterium denitrificans sp. nov., an extremely halophilic denitrifying bacterium. Int J Syst Bacteriol 1986, 36:66-70.

63. Moreno-Vivián C, Ferguson SJ: Definition and distinction between assimilatory, dissimilatory and respiratory pathways. Mol Microbiol I 198, 29(2):664-666.

64. Spiro S: The FNR family of transcriptional regulators. Anton Leeuwenhoek Int J Gen M 1994, 66:23-36.

65. Unden G, Becker S, Bongaerts J, Holighaus G, Schirawski J, Six S: $\mathbf{O}_{2}$ sensing and $\mathrm{O}_{2}$-dependent gene regulation in facultatively anaerobic bacteria. Arch Microbiol 1995, 164:81-90.

66. Elsen S, Swem LR, Swem DL, Bauer CE: RegB/RegA, a highly conserved redox-responding global two-component regulatory system. Microbiol Mol Biol Rev 2004, 68:263-279.

67. Wünsch P, Zumft WG: Functional domains of NosR, a novel transmembrane iron-sulfur flavoprotein necessary for nitrous oxide respiration. J Bacteriol 2005, I87:| 992-200 I.

68. Saunders NF, Houben EN, Koefoed S, de Weert S, Reijnders WN, Westerhoff HV, de Boer AP, Van Spanning RJM: Trasncription regulation of the nir gene cluster encoding nitrite reductase of Paracoccus denitrificans involves NNR and NiRI, a novel type of membrane protein. Mol Microbiol 1999, 34:24-36.

69. Studholme DJ, Pau RN: A DNA element recognised by the molybdenum-responsive transcription factor ModE is conserved in Proteobacteria, green sulphur bacteria and Archaea. BMC Microbiol 2003, 2:3-24.

70. Philippot L: Denitrifying genes in bacterial and archaeal genomes. Biochim Biophys Acta 2002, I 577:355-376.

71. Blasco R, Martínez-Luque M, Madrid MP: Rhodococcus sp. RB I grows in the presence of high nitrate and nitrite concentrations and assimilates nitrate in moderately saline environments. Arch Microbiol 200 I, I 75:435-440.

72. Ventosa A, Nieto J], Oren A: Biology of moderately halophilic aerobic bacteria. Microbiol Mol Biol Rev 1998, 62:504-544.
73. Legaz F, Primo-Millo E: Influencia de la fertilización nitrogenada en la contaminación por nitratos de las aguas subterráneas. Levante Agrícola 1992, 3 1 8:4-15.

Publish with Bio Med Central and every scientist can read your work free of charge

"BioMed Central will be the most significant development for disseminating the results of biomedical research in our lifetime. "

Sir Paul Nurse, Cancer Research UK

Your research papers will be:

- available free of charge to the entire biomedical community

- peer reviewed and published immediately upon acceptance

- cited in PubMed and archived on PubMed Central

- yours - you keep the copyright
BioMedcentral 